\title{
Russia in the Post-Cold War International Order
}

Barry Buzan

\author{
Barry Buzan \\ London School of Economics and Political Science, UK \\ Department of International Relations \\ Professor Emeritus; \\ LSE IDEAS \\ Senior Fellow; \\ The British Academy \\ Fellow; \\ Copenhagen University, Jilin University, China Foreign Affairs University, and University of \\ International Relations, Beijing, China \\ Honorary Professor \\ ORCID: 0000-0002-7922-5194 \\ E-mail:b.g.buzan@lse.ac.uk
}

DOI: $10.31278 / 1810-6374-2021-19-4-22-35$

\begin{abstract}
This paper argues that while Russia has always had a strong need to be acknowledged as a great power, its ability to sustain that position has been under question since the onset of global modernity during the 19th century. Although generally able to sustain a plausible military profile, Russia has been amongst the less successful modern states in economic terms, not least because of its difficulty in establishing an efficient relationship with capitalism. This unbalanced development continues in place today and shows no sign of changing. Russia's decision to link itself strategically to China, puts its great power status increasingly at risk as it becomes an evermore junior partner to the rising Asian giant.
\end{abstract}

Keywords: modernity, great power, international order, Russia, China, strategic partnership. 
7 begin this short opinion piece by setting out what I see as the general historical background - the unfolding story of modernityagainst which any contemporary assessment of Russia, or indeed any country, has to be made. I then look at a number of key points relevant to the particular position of Russia since the late 18th/early 19th century in that story. The unfolding of modernity has two rounds: the first covering the 19th and most of the 20th century and centred on the rise of the West plus Japan; and the second beginning in the 1970s and in full swing by 2020, centering on the wider spread of modernity, particularly in Asia. ${ }^{1}$ I am not an expert on Russia itself, although I have a reasonable general knowledge of the country and its history. My principal contribution here is to look at Russia from outside, from the perspective of global international society. I will mainly assess the position of Russia since the end of the Cold War in the context of what I see as an accelerating shift to a post-Western global order which I characterize as deep pluralism. ${ }^{2}$ The shift to deep pluralism is the opening phase of the second round of modernity. I will also draw on English School ideas about great power responsibility and great power management (GPM) (Bukovansky et al., 2012; Buzan, 2014, pp. 103-4, 145-47). Post-Western does not mean that the West disappears. Rather it means that the West goes from being a hegemonic core during the first round of modernity, to, in the second round, being one among several centers in a global society characterized by a wider diffusion of wealth, power, and cultural and political authority than has been the case for the last two centuries.

The implosion of the Soviet Union and the re-emergence of Russia thirty years ago, was one part of the story of the winding down of the first round of modernity in which a relatively small core of industrialized countries had dominated the planet since the early 19th century. The Soviet Union was one of a number of experiments during the 20th century to create a morally and functionally superior form of industrial political economy to take modernity forward: liberal democracy, social democracy, communism, and fascism. For

For the full story of the two rounds of modernity, see: Buzan, forthcoming.

2 On deep pluralism see: Buzan and Lawson, 2015, Ch. 9; Acharya and Buzan, 2019, Ch. 9. 
a few decades, it had what seemed like a promising run as a viable and attractive model for modernity. After the Second World War, although battered itself, it was surrounded by geopolitical weakness all around Eurasia, and enjoyed a short run as a superpower. Japan and Europe were in ruins, and the Soviet Union occupied much of Eastern and Central Europe, and briefly Manchuria. China was devastated by Japanese occupation, and still embroiled in a long civil war. Colonial empires in the Middle East, South Asia and Southeast Asia were crumbling. Only the distant U.S. could stand against it. In the end, however, the Soviet experiment failed. It created a quite successful military-industrial complex and warfare state. But its totalitarian form, while preferable to fascism, ${ }^{3}$ was not obviously morally superior to, or socially more attractive than, either social- or liberal-democratic models of modernity. Its command economy was conspicuously less efficient than capitalist models at extracting a broad spectrum of wealth and power from the resources of modernity. By the 1990s, post-Soviet Russia was surrounded by strength. Even towards the end of the Cold War, Soviet GDP was surpassed by a resurgent Japan, a country with half its population and much less in the way of territory and natural resources. From the 1980s, China began a long, and broadly-based surge in accumulating wealth and power that increasingly left Russia behind. Indeed, the relatively poor economic performance of the Soviet Union, was one reason why communist China abandoned the Soviet and Maoist economic model in the late 1970s, an event of perhaps greater global significance than the end of the Cold War and the implosion of the Soviet Union. India was a rising nuclear power, and Southeast Asia was also achieving a degree of modernization. The Middle East remained turbulent, but with a strong U.S. presence. The U.S. itself seemed to be at the peak of its power with a unipolar moment. The historic geopolitical moment when Russia was surrounded by weakness had evaporated, with no foreseeable prospect of ever returning.

Yet in the end, the ideological struggle for the future of modernity was won neither by liberalism nor communism, but by capitalism,

As indicated by the eventual alliance choices made during the Second World War. 
which proved to be compatible with a wide range of political forms: authoritarian (China), liberal-democratic (Anglosphere), and socialdemocratic (Europe, Japan) (Buzan and Lawson, 2014). Regardless of the politics framing it, capitalism was better than any other system at extracting wealth and power from the resources of modernity.

Since then Russia's story has to be seen against the background of the second round of modernity now picking up speed. The first round of modernity was dominated by a relatively small group of European powers plus the U.S. and Japan, all of which began their successful modernizations during the 19th century. ${ }^{4}$ The second round is defined so far mainly by Asian countries that began successful modernizations from the 1970s. This second round of modernity is about a new group of countries, of which the biggest and most successful is China, achieving enough modernization to join, and expand, the old core of first round modernizers. It is not yet clear how many more countries will be part of the second round. This second round takes place nearly a century after Japan, Russia and Italy closed the ranks of the firstround modernizers. The first round took place under conditions where great power war was allowed and expected, and where conditions for development were open-ended, with virtually no restrictions on what states could do by way of seeking wealth and power. The second round, now picking up speed, will take place under much more constrained conditions. Great power war is now too dangerous and costly to be rational. Environmental limits, particularly climate change, with its constraints on the use of fossil fuels, and pandemics, which have limited travel and tourism, are posing increasing restrictions on how ongoing development can be sustainably pursued, both for leading edge countries and those still trying to catch up.

So how does post-Soviet Russia fit into this emerging second round? Its starting point was not very promising. It was one of the late developers in the first round of modernity, and remained, despite some significant Soviet achievements, amongst the least successful. Whether as Russia or the Soviet Union, it failed conspicuously to match either the consistency or the level of wealth (GDP/capita) of the other first-

Britain, as the first mover, began during the 18th century (Landes, 1969). 
round modernizers. Although the Soviet Union did reasonably well at providing mass education, raising the status of women, and developing a strong science sector, it never came to terms with capitalism as the most effective means of generating rapid growth and innovation. Its industrialization was far more successful at producing military power, than in developing a broadly-based economy that was innovative in both light and heavy industry. Even in its heyday it was at best what Dibb (1988) called an "incomplete superpower." Because of its limited success at generating industrial modernity, Russia has remained economically dependent on the export of fossil fuels, a source of energy that is already being sharply downgraded during the second round of modernity, as the pressure to respond to climate change pushes remorselessly towards an energy transition to renewables.

Looking ahead into the unfolding second round of modernity, three broad questions stand out. Will Russia be able to sustain its status as a great power? Will it find an efficient way of coming to terms with capitalism? And how will it be affected by the position it has taken in the emerging Second Cold War between China and itself on one side, and the West and many of China's neighbors on the other?

\section{RUSSIA'S STATUS AS A GREAT POWER}

As Iver Neumann (2011) insightfully observes, Russia has a deeprooted need to be a great power and cannot accept any lesser status in international society. Before modernity, its big population relative to the European powers, and its ability to mobilize large armies, covered this need without too much difficulty. But since the 19th century, Russia's late start and relatively weak performance in the first round of modernity have made its great power status an ongoing question. That question was reinforced by periodic defeats and/or internal upheavals: $1856,1905,1918,1989-1991$. The key issue, as the second round of modernity unfolds, is what the balance will be between Russia's need and desire to be a great power, and its capacity to maintain that status? This issue has not gone away and acquires new forms and salience as Russia charts its path into the second round of modernity. It was very obvious during the 1990s heyday of U.S. "unipolarity" and 
globalization, when a reduced, humiliated, and crisis-ridden Russia struggled to rebuild a shattered economy, and to retain great power status. That immediate transition crisis was averted by Putin's act of will in reassembling Russia’s military credibility, and acting like a great power not only in its neighborhood (Ukraine, Syria), but also in the style of its relations with the EU, China, and the U.S.

But the underlying weaknesses of Russia's economy, society, and polity have not gone away. In the second round of modernity, its weaknesses have to compete not only with its traditional first-round rivals in Europe, the U.S. and Japan, but also with a new set of rising powers. China, India, and others are plausibly bidding for great power status too, and their rise adds to the competition for the top places in the international power rankings. From this point of view, unappetizing though it may be for Russians to think this way, Russia is part of the relative decline of the West, or more accurately of the first-round modernizers. Along with the U.S., Europe, and Japan, it faces intensifying competition from the new set of rising powers. In this emerging world order, Russia has relatively little social capital in international society. Its foreign policy style has traditionally been, and remains, a hard form of pluralism, privileging raison d'etat and caring little about raison de système. ${ }^{5}$ It has few firm friends, and unlike China and the U.S., insufficient resources to buy support. Murders of Russian opposition figures abroad sully its reputation, and its denials of responsibility for these are not widely believed.

The numbers do not suggest that Russia is in a strong position to hang on to a place in the top tier of powers. It ranks 11th in global GDP comparisons, below Italy, Canada and South Korea, with a GDP about a tenth the size of China. ${ }^{6}$ It ranks 55th in GDP per capita at purchasing power parity, below Greece and Maylasia. ${ }^{7}$ Russia has a relatively low fertility rate (1.5-1.6), about the same as China, above Japan and Germany, but below the U.S. and the UK, and well below replacement rate. Like many other first-round modernizers, during the 21 st century

Watson (1992, p. 14) defined as "the belief that it pays to make the system work."

6 https://databank.worldbank.org/data/download/GDP.pdf [Accessed 16 August 20210]. https://databank.worldbank.org/data/download/GNIPC.pdf [Accessed 16 August 2021]. 
it faces a severe population decline with all of its consequences (Bricker and Ibbitson, 2019). ${ }^{8}$ Russia gives a comparatively very low percentage of its gross national income for overseas development aid ( 0.075 percent for 2019, compared to 1.15 for Turkey, 1.39 for Poland, 0.292 for Japan, and 0.704 for the UK). ${ }^{9}$ Russia has taken a back-seat role in climate change negotiations and has deep domestic divisions on the subject (Averchenkova, forthcoming). It has played a mainly negative role on the issue of climate change (Buzan and Falkner, forthcoming 2022, p. 29). The climate action tracker assesses Russia's commitment to carbon emissions targets as "critically insufficient". ${ }^{10}$ Russia will get a mix of costs and benefits from the current and likely impacts of climate change. Its benefits will most obviously be in the opening up of the Arctic sea routes, and a milder climate. Its costs will be most obviously in vulnerability to rising sea levels, and the instability of its Arctic permafrost areas becoming vulnerable to fires and huge emissions of greenhouse gases. Because of the narrow base of its industrial economy, it is also vulnerable to falling worldwide demand for fossil fuels during the energy transition.

In sum, Russia cannot be secure in its great power status. Its trump cards are military strength, especially nuclear weapons and delivery systems; its retention of a seat in the P5 of the UN Security Council; and its huge geographic spread. In nearly all other respects, however, it is losing ground to both the other first-round modernizers, and the rising powers in Asia. Its nuclear arsenal is the main support of its great power claim. It has a considerable capacity for what might be called "nuisance power" around its fringes and in cyberspace but has few economic or ideological tools at its disposal.

\section{RUSSIA AND CAPITALISM}

One of the reasons why Russia's great power status hangs by a thread is its longstanding failure to come to terms with capitalism. Although,

\footnotetext{
8 https://data.worldbank.org/indicator/SP.DYN.TFRT.IN?locations=RU https://www.cia.gov/ the-world-factbook/field/total-fertility-rate/country-comparison [Accessed 17 August 2021].

9 https://data.oecd.org/oda/net-oda.htm [Accessed 16 August 2021].

$10 \mathrm{https} / /$ climateactiontracker.org/countries/russian-federation/fair-share/ [Accessed 16 August 2021].
} 
like all of the other leading powers both old and new, Russia is capitalist now, aside from its small elite of rich oligarchs, it is still amongst the least effective of the first-round great powers at extracting a broad spectrum of wealth and power from the resources of modernity. Crucially, it is much less effective at this than the leading second-round power, China, which is developing the full range of quality civilian consumer goods that neither the Soviet Union nor Russia managed to do. Russia remains competitive in military production, but its economy remains heavily tied to the export of fossil fuels at a time when there is a major drive to shift to renewable energy resources as the front-line response to climate change.

Russia's unhappy relationship with industrial capitalism goes back to the 19th century. Like others at the time, it began to develop industrial capitalism under an absolutist monarchy, but this combination proved impossible everywhere given the radical changes in class structure and national politics wrought by industrial capitalism. Russia’s particular exit was into the command economy of a communist dictatorship. As noted above, this was one of a number of experiments during the 20th century in how best to order the political economy of modernity. In the wake of the First World War's national mobilizations, command economy looked plausible, and for a few decades it seemed to perform competitively. But its limits and weaknesses outside heavy industry and armaments were becoming all too evident by the 1970s. During the Soviet period, Russia set itself strongly in opposition to capitalism, a position that resonated with what Neumann (1996) labels the "Slavophile," anti-Western thread in Russian politics and identity. Its tumultuous exit from command economy before and after the end of the Cold War undid much of what the Soviet Union had achieved. It led Russia into an inefficient form of crony capitalism with a lot of state intervention, which made a few people very rich indeed, but provided little momentum away from either the military-industrial complex or dependence on fossil-fuel exports. Russia's GDP is about half that of the UK, and despite all of Japan's economic troubles since the 1990s, Japan's GDP is still well over three times as big as Russia's. ${ }^{11}$ Russia has yet to find a comfortable and efficient relationship with capitalism.

11 https://databank.worldbank.org/data/download/GDP.pdf [Accessed 16 August 2021]. 
An ironic twist to Russia's story here is the role it unintentionally played in inspiring Deng Xiaoping to start thinking hard about the relationship between the market and socialism. While studying in the Soviet Union during the 1920s, the young Deng experienced the ideas of Nikolai Bukharin, and the dramatic effect of the market on production during the New Economic Policy (NEP), when Lenin briefly allowed the market to operate as a way of addressing the many economic shortages left over from the disruptions of the First World War and the Revolution. The experience of the NEP stuck with Deng and resurfaced in China in the group around him in the late 1970s. After the economic chaos of the Mao era, Deng and his supporters were looking for a way to increase production quickly, and were open to exploring forms of "market socialism". Unlike Bukharin, who saw market socialism as a temporary phase on the way to orthodox socialism, Deng's team saw market socialism as a permanent form of development within socialism (Pantsov and Levine, 2015, pp. 6-7, 38, $57,370-73,391)$. The collapse of the Soviet Union also provided sharp lessons for China in how not to pursue reform of a communist political economy. Russia thus helped to enrich and empower its giant neighbor, while failing to do the same for itself. The NEP inspired the astonishing transformation of China since the 1980s that has left Russia and many others economically in the dust.

\section{RUSSIA'S POSITION IN THE SECOND COLD WAR}

For the past decade or so, and especially since its seizure of territory from Ukraine in 2014, Russia has been drifting steadily into an evercloser strategic partnership with China (Cox, 2016). This partnership rests mainly on their mutual antagonism to U.S. dominance within the existing world order, and its use of that to promote liberal values. It is specifically useful to both sides in various ways. It gives Russia economic and political alternatives to Europe after its breach of relations with the West in 2014. It secures China's back in the north, facing more effectively the east and the south. And it helps both to stabilize what might otherwise be a more competitive relationship in Central Asia, especially so now that the U.S. has withdrawn from 
Afghanistan, leaving the region more to its own devices and the management of the local powers.

But this convenient strategic partnership is about to enter a new phase as Xi Jinping's China enters into its own Cold War against the West and many of China's neighbors. This development could well pull Russia into a closer relationship with China, putting pressure on it to upgrade their strategic partnership into some form of alliance. By 2020 it seemed entirely possible that a new Cold War between the West and China was beginning. Economic incompatibility was the background story, as China played a hard game of self-interest and power, and hopes for significant convergence of norms and practices of capitalism faded. Hong Kong was the immediate trigger as the Chinese party/state harshly suppressed democratic dissent, trashing the "two-systems" part of the transition arrangements with Britain, and openly revealing its ruthlessness and lack of concern about, or even interest in, foreign opinion. This was done in a context of opportunistically fluctuating foreign policy, which sustained coercive pressure on India, Japan and Southeast Asia, at the same time intensifying domestic control and repression. During 2020, these moves pushed much of Western opinion outside the U.S., which had previously been happy to rub along with China on economic grounds, into alignment with the American disposition to see China as a threat. The "hedging" behavior of China's neighbors to the east and south has begun to shift towards adversarial balancing, most notably in the strengthening of the Quad grouping of democracies: India, Japan, Australia, and the U.S. There were growing concerns around Taiwan in 2021, and when and how China might enforce its claim; about how the U.S. capability to deter China is waning; and about Xi Jinping's desire to claim the mantle of finishing the civil war by reincorporating Taiwan (The Economist, 20 February 2021: 49).

It might be that Putin's Russia would welcome this development for much the same reason as the current Chinese leadership seems to do: that a hostile international environment gives them legitimation for strengthening domestic control. Russia and China are already conducting joint military exercises together, and Russia has to some 
extent reengaged aspects of its First Cold War with the West. It made itself a major player in the Syrian crisis in 2012-2013, challenging the weakening U.S. position there. Competition between the two sides in Ukraine led to Russia's seizure of some territory there in 2014, and the imposition of Western sanctions. Russia sold advanced S-400 surfaceto-air missile systems to Turkey, a NATO ally, in 2016. Since then, many aspects of the old Cold War have reappeared, such as regular cat-and-mouse games between armed forces in the air and at sea, sensitivity about frontier tripwires, and assassinations of Russian opposition figures abroad. Alongside these are new elements, most notably an ongoing cyberwar played at many levels. Up to a point, Russia seems happy to reengage in such Cold War games with the West in order to burnish its claims to great power status and cater to nationalist opinion. Western economic sanctions mean that there is less to lose economically, and the risk of these relatively low-level confrontations escalating to all-out war has been low.

But while a Sino-Russian quasi alliance in a Second Cold War might have some short-term attractions for Russia, the longer-term implications are more worrying. A full-blown Second Cold War would harden the lines between the two camps, locking Russia more firmly to China, and reducing its diplomatic flexibility. It could also raise the risk of more open military conflict as China grows relatively stronger. Putin has so far seemed content to trade tactical gains, such as in Ukraine, for putting all of Russia's strategic eggs in one basket: the partnership with China. But one does not have to contemplate the numbers for long to see that such an arrangement has a high risk of tying Russia tightly into a strategic relationship in which it cannot escape being increasingly the junior partner. China's economy is already much bigger than Russia's, and in many ways more sophisticated and broadly-based. Even with the recent slowdown in growth, it is expanding much faster than Russia's, and is already a provider of capital investment on a global scale in a way that Russia has never been. Russia's one comparative advantage, its greater expertise in military, nuclear, and space technology, is eroding rapidly. 
The prospect for Russia is therefore to be progressively and rapidly overshadowed by its partner/ally. As China gets relatively stronger, and the West gets relatively weaker, how does Russia fit into this equation? At what point does its threat calculation flip? The relative decline of the West reduces both its global role and its physical and normative threat to Russia, thus reducing the principal shared interest between Russia and China. And as China's rise expands the wealth and power gap with Russia, and makes China increasingly the dominant partner, how will Russia deal with that? At what point will Russia start to feel more threatened by a powerful China than by a no longer globally dominant West? If it stays with the China partnership, how does it avoid being swallowed up by it? If it tries to leave, what are its options? This quandary of Putin's making raises three subsidiary questions:

1. How much appetite does Russia have for a higher-level of confrontation with the West that its strategic partnership with China makes more probable?

2. As Russia burns its diplomatic and economic bridges to the West and Japan, what options does it leave itself should it want to exit the partnership with China?

3. How can Russia square its deeply rooted need to be an independent, front-rank great power, with its diminishing status in relation to a rising China?

For the last two centuries, Russia has faced a long struggle to retain its great power status and has undergone many ups and downs. That pattern shows no sign of disappearing. Having only barely avoided sinking to the regional power level during the 1990s and reasserted a plausible great power standing during the first two decades of the 21st century, Russia now once again faces questions. As one of the least successful modernizers of the first round, it has tied its fortunes to the most successful of the second-round modernizers. Throughout this history Russia has remained dependent on military strength, and since the 1950s particularly nuclear weapons, to underpin its great power claim. Its economy has always been relatively weak, and there is no sign that 
this unbalanced profile is going to change. Exacerbating this situation is the fact that Russia is increasingly at odds with the rising salience of climate change in world affairs, and the consequent accelerating shift away from fossil fuels. Russia might get some benefits from a warmer climate, but it is vulnerable to sea-level rise. Since the Arctic is warming faster than other latitudes, a warming climate could also cause a lot of harm to Russia's ecology and infrastructure, and a difficult transition period. Although Russia will almost certainly be able to retain a nuclear deterrent, it may well, like Britain, find itself increasingly slipping down the power rankings as China and other emerging economies add their new weight and influence into an expanded global core. How all this plays not just into Russia's foundational identity as a great power, but also into its domestic debates between Slavophiles and Westernizers, is to my mind the question that Russia needs to be thinking about on the thirtieth anniversary of its latest incarnation.

\section{References}

Averchenkova, Alina, forthcoming. Great Power Ambitions and National Interest in Russia's Climate Change Policy. In: Robert Falkner and Barry Buzan (eds.). Great Power Responsibility and Global Environmental Politics, Ch. 8. Oxford: Oxford University Press.

Acharya, Amitav and Barry Buzan, 2019. The Making of Global International Relations. Cambridge: Cambridge University Press.

Bricker, Darrell, and John Ibbitson, 2019. Empty Planet: The Shock of Global Population Decline. London: Robinson.

Bukovansky, M., Clark, I., Eckersley, R., Price, R., Reus-Smit, C. and Wheeler, N., 2012. Special Responsibilities: Global Problems and American Power. Cambridge: Cambridge University Press.

Buzan, Barry, 2014. An Introduction to the English School of International Relations. Cambridge: Cambridge University Press.

Buzan, Barry, forthcoming. Global Society.

Buzan, Barry and Lawson, George, 2014. Capitalism and the Emergent World Order. International Affairs, 90(1), pp. 71-91. 
Buzan, Barry and Lawson, George, 2015. The Global Transformation: History, Modernity and the Making of International Relations. Cambridge: Cambridge University Press.

Buzan, Barry and Falkner, Robert, forthcoming 2022. Great Powers and Environmental Responsibilities: A Conceptual Framework. In: Robert Falkner and Barry Buzan (eds.) Great Power Responsibility and Global Environmental Politics, Ch. 2. Oxford: Oxford University Press.

Cox, Michael, 2016. Not just 'convenient': China and Russia's New Strategic Partnership in the Age of Geopolitics. Asian Journal of Comparative Politics, 1(4), pp. 317-334.

Dibb, Paul, 1988. The Soviet Union: The Incomplete Superpower. Basingstoke: Macmillan.

Landes, David S., 1969. The Unbound Prometheus. London: Cambridge University Press.

Neumann, Iver B., 1996. Russia and the Idea of Europe: A Study in Identity and International Relations. London: Routledge.

Neumann, Iver B, 2011. Entry into International Society Reconceptualized: The Case of Russia. Review of International Studies, 2(37), pp. 463-84.

Pantsov, Alexander V. and Levine, Stephen I., 2015. Deng Xiaoping: A Revolutionary Life. New York: Oxford University Press.

Watson, Adam, 1992. The Evolution of International Society. London: Routledge. 